\title{
ENDOPARASITES OF WILD BIRDS FROM CAMPUS AREA AND ZOOBOTANICAL PARK, AT THE FEDERAL UNIVERSITY OF ACRE, RIO BRANCO - ACRE
}

\author{
Angela Silva de Almeida Brito ${ }^{1}$ \\ Edson Guilherme ${ }^{2}$ \\ Francisco Glauco de Araújo Santos ${ }^{2}$ \\ Rosiane Portela de Mesquita ${ }^{1}$ \\ Fábio Augusto Gomes ${ }^{2}$
}

BRITO, A. S. de A.; GUILHERME, E.; SANTOS, F. G. de A.; MESQUITA, R. P. de; GOMES, F. A. Endoparasites of wild birds from Campus area and Zoobotanical Park, at the Federal University of Acre, Rio Branco -Acre. Arq. Ciênc. Vet. Zool. UNIPAR, Umuarama, v. 20, n. 3, p. 117-122, jul./set. 2017.

\begin{abstract}
This study was developed at the Campus (C) and the Zoo-botanical Park (PZ) at the Federal University of Acre, with the purpose of identifying endoparasites in the avifauna of those locations. The birds were captured using 10 mist nets. The nets were set from 1 p.m. to 5 p.m.. The faecal samples collected were stored in Merthiolate, Iodine and Formaldehyde (MIF). Willies and direct methods were used for the diagnostic of endoparasites. Two hundred and eighty-seven birds were captured, with 34 recaptures, which resulted in 253 different specimens - 158 on the campus and 95 at the PZ. The birds caught were from 58 different species, belonging to 25 families and 12 orders. Fecal samples from 193 birds belonging to 49 species from 11 orders and 18 families were obtained and analyzed. The following endoparasites were identified: Eimeria sp., Entamoeba coli, Entamoeba histolytica, Iodamoeba bütschlii, Isospora sp., Enterobius vermicularis, Heterakis gallinarum, Ascaridia galli, Strongyloides avium, Capillaria spp., Ancylostoma spp., Raillietina sp., Choanotaenia sp., Microphallus sp., and Echinostoma revolutum. Eimeria sp. was the most frequent parasite found in most bird species. The results showed a high level of endoparasitic infection in the aviary community in the two study areas.
\end{abstract}

KEYWORDS: Acre. Amazon. Avifauna. Eimeria.

\section{ENDOPARÁSITOS EN AVES SILVESTRES DEL ÁREA DEL CAMPUS Y DEL PARQUE ZOOBOTÁNICO DE LA UNIVERSIDAD FEDERAL DEL ACRE, RIO BRANCO - ACRE}

RESUMEN: El estudio se realizó en el Campus (C) y en el Parque Zoobotánico (PZ), de la Universidad Federal de Acre, con el objetivo de identificar los endoparásitos presentes en la avifauna de estos locales. Las aves fueron capturadas utilizando 10 redes de niebla. Las redes fueron armadas en el período de las $13 \mathrm{~h}$ a las $17 \mathrm{~h}$. Las muestras fecales obtenidas se conservaron en Merthiolate, Yodo y Formaldehído (MIF). Para el diagnóstico de los endoparásitos se utilizaron los métodos directo y de Willis. Se capturaron 287 aves, habiendo ocurrido 34 recapturas, lo que resultó en 253 especímenes distintos, siendo 158 en el Campus y 95 en el PZ. Las aves capturadas pertenecían a 58 especies, distribuidas en 25 familias y 12 órdenes. Se obtuvieron y analizaron las muestras fecales de 193 aves, pertenecientes a 49 especies de 11 órdenes y 18 familias. Los endoparásitos identificados: Eimeria sp., Entamoeba coli, Entamoeba histolytica, Iodamoeba butschlii, Isospora sp., Enterobius vermicularis, Heterakis gallinarum, Ascaridia galli, Strongyloides avium, Capillaria sp., Ancylostoma sp., Raillietina sp., Choanotaenia sp., Microphallus sp. y Echinostoma revutum. La Eimeria sp. fue el parásito que estuvo presente en mayor número de especies de aves. Los resultados evidenciaron un alto nivel de infección de endoparásitos en la comunidad de aves, presentes en las dos áreas del estudio.

PALABRAS CLAVE: Acre. Amazonia. Avifauna. Eimeria.

\section{ENDOPARASITAS DE AVES SILVESTRES DA ÁREA DO CAMPUS E DO PARQUE ZOOBOTÂNICO, DA UNIVERSIDADE FEDERAL DO ACRE, RIO BRANCO - ACRE}

RESUMO: O estudo foi realizado no Campus (C) e no Parque Zoobotânico (PZ), da Universidade Federal do Acre, com o objetivo de identificar os endoparasitas presentes na avifauna destes locais. As aves foram capturadas utilizando-se 10 redes de neblina. As redes foram armadas no período das $13 \mathrm{~h}$ às $17 \mathrm{~h}$. As amostras fecais obtidas foram conservadas em Merthiolate, Iodo e Formaldeído(MIF). Para diagnóstico dos endoparasitas foram utilizados os métodos direto e de Willis. Foram capturadas 287 aves, tendo ocorrido 34 recapturas, o que resultou em 253 espécimes distintas, sendo 158 no Campus e 95 no PZ. As aves capturadas pertenciam a 58 espécies, distribuídas em 25 famílias e 12 ordens. Foram obtidas e analisadas as amostras fecais de 193 aves, pertencentes a 49 espécies de 11 ordens e 18 famílias. Os endoparasitas identificados: Eimeria sp., Entamoeba coli, Entamoeba histolytica, Iodamoeba butschlii, Isospora sp., Enterobius vermicularis, Heterakis gallinarum,

\footnotetext{
DOI: 10.25110 /arqvet.v20i3.2017.6363

${ }^{1}$ Mestre - Pós-Graduação em Ciências, Inovação e Tecnologia para Amazônia - Universidade Federal do Acre, UFAC, Rio Branco, AC, Brasil, E-mail: angelabrito16@gmail.com; rosiiportela@gmail.com

${ }^{2}$ Professor Doutor - Centro de Ciências Biológicas e da Natureza - Universidade Federal do Acre, UFAC, Rio Branco, AC, Brasil, E-mail: guilherme@ufac. br; edson@uol.com.br; fcoglauco@ufac.bre augusto.ufac@gmail.com
} 
Ascaridia galli, Strongyloides avium, Capillaria sp., Ancylostoma sp., Raillietina sp., Choanotaenia sp., Microphallus sp. e Echinostoma revolutum. A Eimeria sp. foi o parasito que esteve presente em maior número de espécies de aves. Os resultados evidenciaram um alto nível de infecção de endoparasitas na comunidade de aves, presentes nas duas áreas de estudo.

PALAVRAS-CHAVE: Acre. Amazônia. Avifauna. Eimeria.

\section{Introduction}

The birds are a group of vertebrates found in virtually all regions of the planet. Birds are among the most easily-recognized of animals, due to their ample geographic distribution, and the predominantly diurnal habits of most species (SICK, 1985).

Wild birds are subject to a variety of health problems, which may affect their survival and reproduction. Parasitic infestation is one of the most prominent of these problems, not only because of the frequency of occurrence, but also due to their potential impact, provoking serious infections and even death in a large proportion of the bird populations found in intensely parasitized regions (REED et al., 2003; MARIETTO et al., 2009).

Parasitism has been reported in birds by a number of authors (FREITAS et al., 2002; LUZ et al., 2005; JACOBSEN et al., 2006; MARIETTO et al., 2009). The most common avian endoparasites are protozoa, nematodes, cestodes, and trematodes (REY, 2008).

Eimeria and Isospora are among the most prominent protozoan parasites of birds, bothdomestic and wild species, causing persistent illness, especially in captivity (MARIETTO et al., 2009).

Eimeria causes coccidiosis, a common infectious disease in birds, usually limited to the digestive tract. Infection occurs through ingestion of oocysts found in the nest, soil, food or contaminated water. After ingestion, the protozoa through a series of intracellular and extracellular stages, asexual and sexual, to produce viable oocysts which are excreted in the feces (ROSE, 1987).

Nematodes are considered to be the most pathogenic endoparasites, and may have a considerable economic impact on the poultry industry. The occurrence of infections by these endoparasites is more common in free-range domestic birds and in the wild, but it is relatively uncommon in confined poultry (TAYLOR et al., 2010). These parasites may be transmitted horizontally, directly between birds, through the ingestion of larvae, or by the indirect cycle, which requires an intermediate host, such as a mollusc or an insect. Nematodes include Syngamus trachea, Dispharynx, Tetramers, Ascaridia, and Capillaria (TAYLOR et al., 2010).

While they are less pathogenic than nematodes, cestodes can also cause disease in birds, in particular, severe hemorrhagic enteritis. This endoparasite is also important because of its ability to infect a large number of individuals in a population. Over a thousand species of cestodes have been identified in domestic and wild birds, such as Davinea proglottina and Raillietina tetragona (TAYLOR et al., 2010).

The trematodes that infect the bird intestine include Echistoma revolutum, which can cause diarrhea, malnutrition and fatigue. A high parasite load of this worm can lead to death through the perforation of the intestine of the infected individual (TAYLOR et al., 2010).

The identification of endoparasites is essential for the understanding of the prevalent species that infect a wild bird fauna, in addition to the development and implementation of effective measures of control. In this context, the present study aimed to identify the endofauna of wild birds captured on the campus and the adjacent Zoobotanical Park, which are part of the Federal University of Acre in Rio Branco, in the western Brazilian Amazon basin.

\section{Materials and Methods}

Birds were captured for the collection of fecal samplesin two areas of the Federal University of Acre (UFAC), the Campus (C) proper, and the adjacent Zoobotanical Park (ZP). The UFAC campus is located in the urban zone of Rio Branco, the capital of the Brazilian state of Acre, which is located $7 \mathrm{~km}$ from the city center, on the BR-364 federal highway.

Birds were captured between September 2014 and March 2015.Ten mist-nets (12 m x 2 m x 36 mm) were used, and were installed close to the ground, being set for four hours per day (13:00-17:00 h) on two days a week at each collection site. The nets were inspected regularly, according to the frequency of captures.

The captured birds were marked with numbered metal rings provided by CEMAVE/IBAMA. The bird species were identified by Dr. Edson Guilherme and the biologist Rosiane Portela, both of the UFAC Ornithology Laboratory. The scientific nomenclature of the Brazilian Committee of Ornithological Records (CBRO, 2014) was applied for the identification of the species.

Once identified and banded, the birds were placed in cloth bags containing absorbent paper until they defecated or up to a maximum of 40 minutes. The birds were then released, even if they had not defecated by the end of the 40-minute period. The fecal samples obtained from each bird were packed separately in plastic pots containing a preservative solution of Merthiolate-Iodine-Formaldehyde (MIF) for subsequent parasitological examination. The presence of endoparasites was diagnosed using the direct and Willis-Mollay methods, as described by De Carli (2001), using 10x and 40x lenses for the visualization and identification of the parasitic forms. This study was approved by the UFAC Ethics Committee on the Use of Animals (CEUA-UFAC), and the collection of wild animals was authorised by SISBIO 232691.

\section{Results and Discussion}

During the study, a total of 287 birds were captured, representing 253 different individuals and 34 recaptures. Of this total, 158 individuals were captured on the Campus, and 95 in the Zoobotanical Park. The captured birds belonged to 58 species, representing 25 families and 12 orders. In a previous study at UFAC between July 1998 and February 2000, Guilherme (2001) recorded 150 bird species in 36 families, using seven mist nets and complementary observations with binoculars.

Fecal samples were obtained from 193 birds (130 
from the Campus and 63 from the Zoobotanical Park), belonging to 49 species in 18 families and 11 orders. A total of 15 endoparasite species were recorded in the parasitological analyses: Eimeria sp., Entamoeba coli, Entamoeba histolytica, Isospora sp., Iodamoeba butschlii, Ancylostoma sp., Ascaridia galli, Strongyloides avium, Capillaria sp., Enterobius vermicularis, Heterakis gallinarum, Raillietina sp., Choanotaenia sp., Microphallus sp., and Echinostoma revolutum. These taxa were identified based on the observation ofoocysts, eggs and larvae under light microscopy (Figure 1).

Figure 1. Endoparasites present in the fecal samplesanalyzed. (A) Eimeria sp., 40x, (B) Entamoeba coli, 40x, (C) Entamoeba histolytica, 40x, (D) Isospora sp.,10x, (E) Iodamoeba butschlii, 40x, (F) Ancylostoma sp., 40x, (G) Ascaridia galli, 40x, (H) Strongyloides avium, 40x, (I) Capillaria sp.,40x, (J) Enterobius vermicularis,40x, (L) Heterakis gallinarum, 40x, (M) Raillietina sp., 40x, (N) Choanotaenia sp., 40x, (O) Microphallussp. 40x, and (P) Echinostoma revolutum, 40x.

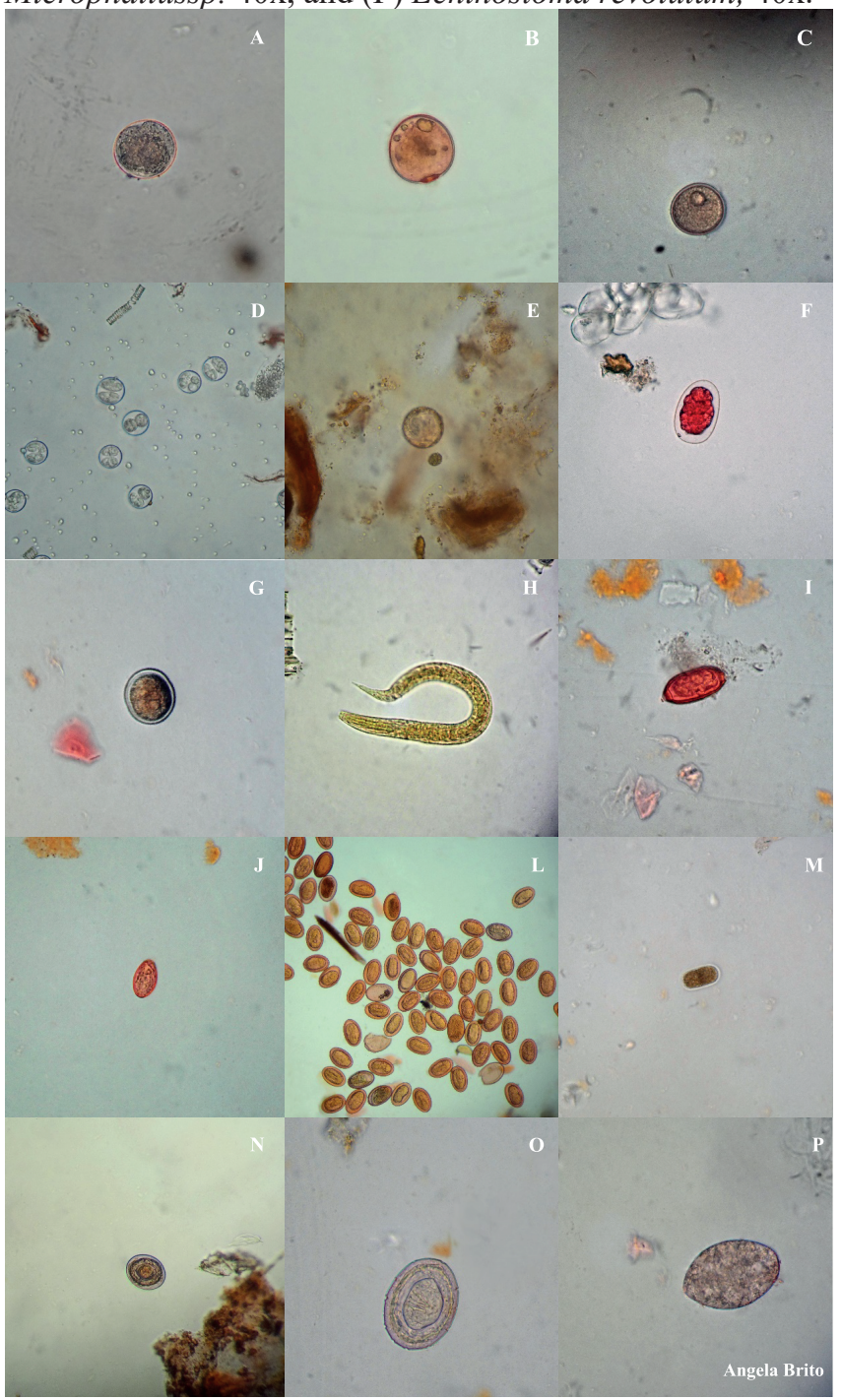

Eimeria sp. and Isospora sp. were the most generalist endoparasite species, being recorded in 23 and 22 bird species, respectively (Table 1). The highest Eimeria sp. infection rate was recorded in Jacana jacana, with 16 of the $20(80 \%)$ birds captured being infected with this parasite. Eimeria sp. was also found in the fecal samples of Chloro- ceryle americana, Cacicus cela, Sturnella militaris, Progne chalybea, Sporophila castaneiventris, Colaptes punctigula and Phaeomyias murina, Tringa solitaria, Columbina talpacoti, Leptopogon amaurocephalus, Brotogeris sanctithomae, Thamnophilus schistaceus, Troglodytes musculus, Ramphocelus carbo, Crotophaga ani, Myiozetetes similis, Turdus ignobilis, Momotus momota, Ammodramus aurifrons, Turdus hauxwelli, Myiozetetes cayanensis, and Tyrannus melancholicus. In a study of the gastrointestinal parasites of pigeons captured in urban areas of Lages, Santa Catarina (Brazil), Marques et al. (2007) found that 86.05\%(37 of 43) of the birds were parasitized by protozoans, with Eimeria sp. oocysts being detected in all cases.

The Isospora sp.infection rate was highest in Turdus ignobilis, with 12 of the $20(60 \%)$ samples analyzed being infected. Isospora sp. was also present in Dendrocygna viduata, Vanellus chilensis, Hemitriccus flammulatus, Cacicus cela, Catharus swainsoni, Cantorchilus leucotis, Pheugopedius genibarbis, Troglodytes musculus, Tangara episcopus, Turdus ignobilis, Turdus hauxwelli, Rhynchocyclus olivaceus, Sporophila castaneiventris and Thamnophilus schistaceus, Ramphocelus carbo, Tringa solitaria, Machaeropterus pyrocephalus, Crotophaga ani, Tyrannus melancholicus, Columbina talpacoti, Pipra fasciicauda, and Jacana.

Eimeria sp. and Isospora sp. are among the endoparasites most commonly found in birds. In a study of wild birds, Marietto et al. (2009) reported that species of five of the 12 ordersanalyzed were infected. The coccidians (Eimeira and Isospora) were the most common parasites, being found principally in individuals of the order Passeriformes.

As the causal agent of coccidiosis, Eimeria sp. is considered to be the most deleterious of the protozoans that cause disease in birds, and is a major problem for the poultry industry. The symptoms caused by this parasite include enteritis and diarrhea, and synergic effects with other diseases can make the infection even more severe (ALLEN; FETTERER, 2002).

In the present study, Capillaria sp. was recorded in the birds Dendrocincla fuliginosa, Cacicus cela, Sporophila castaneiventris, Momotus momota, Jacana, Myiozetetes similis, Turdus ignobilis and Tyrannus melancholis. Capillaria is potentially one of the most pathogenic helminths and may have grave effects on confined poultry. Mapeli et al. (2003) observed natural helminth infections, including Capillaria sp., in partridges being bred in captivity in the municipality of Jaboticabal, São Paulo (Brazil).

Other helminths recorded in the present study included Ascaridia galli, Heterakis gallinarum and Raillietina sp., which were also observed by Giovannoni and Kubiak (2001) during autopsies of domestic animals. These authors recorded A. galli, H. gallinarum and Raillietina boniniem in different portions of the digestive tract of Columba livia domestica.

Strongyloides avium was found in nine bird species at UFAC, Cacicus cela, Sporophila castaneiventris, Momotus momota, Crotophaga ani, Jacana jacana, Turdus ignobilis, Myiozetetes similis, Myiozetetes cayanensis, and Pipra fasciicauda. Between August 2010 and July 2012, Snak et al. (2014) inventoried 228 fecal samples of 37 bird species in 22 enclosures of Danilo Galafassi Municipal Park in Cascavel, Paraná (Brazil), and recorded five parasite genera, 
Strongyloides, Eimeria, Capillaria, Deletrocephalus, and Isospora.

Here, Entamoeba histolytica was found in the birds Sporophila castaneiventris, Aratinga weddellii, of Tringa solitaria, Ammodramus aurifrons, Jacana jacana, Ramphocelus carbo, Columbina talpacoti, Crotophaga ani, and Tyrannus melancholicus. Entamoeba coli was present in the birds Dendrocincla fuliginosa, Ammodramus aurifrons, Columbina talpacoti, Crotophaga ani, and Jacana jacana. These endoparasites were also reported by Marietto et al. (2009), who recorded Entamoeba sp. in the fecal samples of wild birds held in captivity, which were treated at the Ornithopathology and Parasitic Diseases laboratories at the Veterinary Hospital of the College of Veterinary Medicine and Animal Science at Paulista State University in São Paulo (Brazil).

In the present study, Ancylostoma sp. occurred in the feces of 10 bird species, Geotrygon montana, Jacana jacana, Pitangus sulphuratus, Tringa solitaria, Hypocnemis subflava, Turdus hauxwelli, Turdus ignobilis, Crotophaga ani, Columbina talpacoti, and Myiozetetes similis.Enterobius vermicularis was found in fivebirds, Sturnella militaris, Leptopogon amaurocephalus, Tringa solitaria, Columbina talpacoti and Jacana jacana. Microphallus sp. occurred in seven birds, Tringa solitaria, Jacana jacana, Myiozetetes cayanensis, Tyrannus melancholicus, Myiozetetes similis, Columbina talpacoti and Turdus ignobilis. Choanotaenia sp. was found in six birds, Aratinga weddellii, in Tringa solitaria, Sturnella militaris, Tangara episcopus, Troglodytes musculus, and Turdus ignobilis.

Echinostoma revolutum was present in 11 birds, including all the fecal samples examined from the species Chloroceryle inda, Pheugopedius genibarbis, and Pitangus sulphuratus. It was also found in the feces of Tringa solitaria, Leptopogon amaurocephalus, Momotus momota, Sturnella militaris, Crotophaga ani, Turdus hauxwelli, Jacana jacana and Turdus ignobilis. Iodamoeba butschlii was recorded only in Brotogeris sanctithomae.

Freitas et al. (2002) analyzed wild birds kept in captivity in the Brazilian state of Pernambuco and reported a high incidence of parasites. In this study, 320 of the 685 birds analyzed were parasitized with Capillaria sp., Strongyloides sp., Ascaridia sp., Heterakis sp., Spiruroidea, Cestodea, Trematoda, Coccidia, Entamoeba coli, E. histolytica and Balantidium coli. In addition to these endoparasites, four other taxa were recorded in the present study, Entamoeba coli, Iodamoeba butschlii, Choanotaenia sp. and Echinostoma revolutum, reinforcing the diversity of bird endoparasites found in the study region.

Table 1. Endoparasites identified in the present study, and the bird species in which they were recorded, based on the analysis of fecal samples collected at the Federal University of Acre, in Rio Branco, Brazil.

\begin{tabular}{|c|c|}
\hline Parasite species & Bird species infected \\
\hline Ancylost & $\begin{array}{l}\text { Jacana jacana, Tringa solitaria, Pitangus sulphuratus, Turdus ignobilis, Myiozetetes similis, } \\
\text { Columbina talpacoti, Geotrygon Montana, Crotophaga ani, Hypocnemis subflava, Turdus } \\
\text { hauxwelli. }\end{array}$ \\
\hline Ascaridia galli & $\begin{array}{l}\text { Vanellus chilensis, Jacana jacana, Columbina talpacoti, Crotophaga ani, Hemitriccus } \\
\text { flammulatus. }\end{array}$ \\
\hline Capillaria sp. & $\begin{array}{l}\text { Jacana jacana, Momotus momota, Dendrocincla fuliginosa, Cacicus cela, Sporophila } \\
\text { castaneiventris, Turdus ignobilis, Myiozetetes similis, Tyrannus melancholicus. }\end{array}$ \\
\hline Choanot & $\begin{array}{l}\text { Tringa solitaria, Sturnella militaris, Tangara episcopus, Aratinga weddellii, Turdus } \\
\text { ignobilis,Troglodytes musculus. }\end{array}$ \\
\hline Eimeria sp. & $\begin{array}{l}\text { Jacana jacana, Tringa solitaria, Columbina talpacoti, Chloroceryle americana, Momotus } \\
\text { momota, Crotophaga ani, Cacicus cela, Sturnella militaris, Progne chalybea, Ammodramus } \\
\text { aurifrons, Leptopogon amaurocephalus, Ramphocelus carbo, Sporophila castaneiventris, } \\
\text { Colaptes punctigula, Phaeomyias murina, Brotogeris sanctithomae, Thamnophilus schistaceus, } \\
\text { Turdus ignobilis, Turdus hauxwelli, Myiozetetes cayanensis, Myiozetetes similis, Tyrannus } \\
\text { melancholicus, Troglodytes musculus }\end{array}$ \\
\hline Entamoeba histol & $\begin{array}{l}\text { Jacana jacana, Tringa solitaria, Columbina talpacoti, Crotophaga ani, Ammodramus aurifrons, } \\
\text { Ramphocelus carbo, Sporophila castaneiventris, Aratinga weddellii,Tyrannus melancholicus. }\end{array}$ \\
\hline Entamoeba coli & $\begin{array}{l}\text { Jacana jacana, Columbina talpacoti, Crotophaga ani, Dendrocincla fuliginosa, Ammodramus } \\
\text { aurifrons. }\end{array}$ \\
\hline Echinostoma $r$ & $\begin{array}{l}\text { Jacana jacana, Tringa solitaria, Chloroceryle inda, Momotus momota, Crotophaga ani, } \\
\text { Sturnella militaris, Leptopogon amaurocephalus, Pheugopedius genibarbis, Pitangus } \\
\text { sulphuratus, Turdus ignobilis, Turdus hauxwelli. }\end{array}$ \\
\hline Enterobius Vermicularis & $\begin{array}{l}\text { Jacana jacana, Tringa solitaria, Columbina talpacoti, Sturnella militaris,Leptopogon } \\
\text { amaurocephalus. }\end{array}$ \\
\hline Heterakis $g$ & $\begin{array}{l}\text { Turdus ignobilis, Columbina talpacoti, Crotophaga ani, Sturnella militaris, Machaeropterus } \\
\text { pyrocephalus, Pipra fasciicauda. }\end{array}$ \\
\hline
\end{tabular}




\begin{tabular}{l|l}
\hline & $\begin{array}{l}\text { Dendrocygna viduata, Vanellus chilensis, Machaeropterus pyrocephalus, Pipra fasciicauda, } \\
\text { Hemitriccus flammulatus, Jacana jacana, Tringa solitaria, Columbina talpacoti, } \\
\text { Isospora sp. }\end{array}$ \\
$\begin{array}{l}\text { Crotophaga ani, Cacicus cela, Rhynchocyclus olivaceus, Ramphocelus carbo, Sporophila } \\
\text { castaneiventris, Tangara episcopus, Catharus swainsoni, Cantorchilus leucotis, Thamnophilus } \\
\text { schistaceus, Pheugopedius genibarbis, Turdus ignobilis, Turdus hauxwelli, Tyrannus } \\
\text { melancholicus, Troglodytes musculus. }\end{array}$ \\
\hline Iodamoeba butschlii & Brotogeris sanctithomae \\
\hline Microphallus sp. & $\begin{array}{l}\text { Jacanajacana, Tringa solitaria, Columbina talpacoti, Turdus ignobilis, Myiozetetes cayanensis, } \\
\text { Myiozetetes similis, Tyrannus melancholicus. }\end{array}$ \\
\hline Raillietina sp. & Columbina talpacoti,Turdus ignobilis. \\
\hline Strongyloides avium & $\begin{array}{l}\text { Jacanajacana, Momotus momota, Crotophaga ani, Cacicus cela, Pipra fasciicauda, Sporophila } \\
\text { castaneiventris, Turdus ignobilis, Myiozetetes similis, Myiozetetes cayanensis. }\end{array}$ \\
\hline
\end{tabular}

The present story recorded a considerable diversity (15 species) of endoparasites in the fecal samples of thebirds captured in the grounds of the Federal University of Acre (UFAC). These data represent an important advance in the understanding of the diversity and occurrence of endoparasites in the wild bird fauna of Brazil. The high prevalence of parasites recorded in the present study may have important implications for both bird conservation and public health, as well as potential repercussions for the local poultry industry, which reinforces the need for further research.

Acknowledgments: I thank to the Federal University of Acre, the opportunity to study postgraduate, Master's level.

\section{References}

ALLEN, P. C.; FETTERER, R. H. Recent advances in biology of Eimeria species and diagnosisand control of infection with these coccidian parasites of poultry. Reviews Clinical Microbiology, v. 15, n. 1, p. 58-65, 2002.

CARLI, G. A. de. Parasitologia clínica: seleção de métodos e técnicas de laboratório para o diagnóstico das parasitoses humanas. São Paulo: Atheneu. 2001.

\section{COMITÊ BRASILEIRO DE REGISTROS}

ORNITOLÓGICOS. Listas das aves do Brasil. Disponível em: <http://www.cbro.org.br/Piacentini $\% 20$ et $\% 20$ al $\% 20$ 2015\%20RBO.pdf>. Acesso em: 25 jul. 2014.

FREITAS, M. F. L. et al. Parásitos gastrointestinales de aves silvestres en cautiverio en el estado de Pernambuco, Brasil. Parasitología latinoamericana, v. 57, n. 1-2, p. 50-54, 2002.

GIOVANNONI, M.; KUBIK, G. V. L. Fauna parasitológica paranaense. IV. Lista prévia da ocorrência de helmintos em animais domésticos. Arquivos de Biologia e Tecnologia, Curitiba, v. 2, n. 1, p. 289-292, 2001.

GUILHERME, E. Comunidade de aves do Campus e Parque Zoobotânico da Universidade Federal do Acre, Brasil. Tangara, v. 1, n. 2 p. 57-73, 2001.

JACOSEN, G. et al. Cryptosporidium sp. em intestino, bursa de Fabricius e traquéia de frangos (Gallus gallus).
Ciência rural, v. 36, n. 2, p. 682-684, 2006.

LOPES, L. E. Biologia comparada de Suiriri affinis e Suiriri islerorum (Aves: Tyrannidae) no cerrado do Brasil central. 2004. Dissertação (Mestrado) - Universidade de Brasília, Brasília, 2004.

LUZ, H. R.; FERREIRA, I.; VENTURA, P. E. Estudo da prevalência de ectoparasitos em aves apreendidas no Rio de Janeiro. In: CONGRESSO BRASILEIRO DE ORNITOLOGIA, 12., 2005, Belém - PA. Anais... Belém, 2005. p. 160.

MAPELI, E. B. et al. Infecções naturais por helmintos em perdizes (Rhynchotus rufescens Temminck, 1985) de cativeiro, no município de Jabuticabal, estado de São Paulo. Arquivo Instituto de Biologia, São Paulo, v. 70, n. 4, p. 415-418, 2003.

MARIETTO, G. A. G. et al. Prevalência de endoparasitas em amostras fecais de aves silvestres e exóticas examinadas no Laboratório de Ornitopatologia e no Laboratório de Enfermidades Parasitárias da FMVZ-UNESP/Botucatu-SP. Ciência Animal Brasileira, v. 10, n. 1, p. 349-354, 2009

MARQUES, S. M. T. et al. Parasites of (Columbia livia) in urban área of lages, southern Brasil. Parasitologia Latinoamericana, v. 62, n. 3-4, p. 183-187, 2007.

REED, K. D. et al. Birds, migration and emerging zoonoses: west nile virus, lyme disease, influenza a and enteropathogens. Clinical Medicine and Research, v. 1, n. 1, p. 5-12, 2003.

REY, L. Parasitologia. Rio de Janeiro: Guanabara Koogan, 2008. p. 856.

ROSE, M. E. Immunity to Eimeria infections. Veterinary Immunology and Immunopathology, v. 17, p. 333-343, 1987.

SILVA, A. S. et al. Parasitismo Por Isospora sp. em Agapornis fischeri (Pássaro-do-Amor) criados em cativeiro no Brasil. Caderno de Pesquisa Série Biologia, v. 21, n. 1, p. 53-57, 2009.

SICK, H. Ornitologia brasileira: uma introdução. Brasília: 
Universidade de Brasília, v. 1, n. 2, p. 827, 1985.

SNAK, A. et al. Análises coproparasitológicas de aves silvestres cativas. Ciência Animal Brasileira, v. 15, n. 4, p. 502-507, 2014.

TAYLOR, M. A.; COOP, R. L.; WALL, R. L. Parasitologia veterinária. 3. ed. Rio de Janeiro: Guanabara Koogan,

2010.

Recebido em: 20.09.2017

Aceito em: 23.12.2017 